\title{
APPLICATION OF FACTOR ANALYSIS IN COMPANY MANAGEMENT - SELECTED EXAMPLES RELATED TO COMPETITIVENESS AND MARKET SUCCESS
}

\author{
JOLANTA JURCZAK ${ }^{(1)}$ GRZEGORZ JURCZAK ${ }^{(0)}$
}

\begin{abstract}
A B S T R A C T
Factor analysis is a standard statistical technique for reducing data dimensionality, which is widely used in sociology, psychology, and demography. Also, financial and insurance institutions commonly use such a technique for marketing research. In recent years, factor analysis has been used, at the beginning rather diffidently, to analyse selected problems of business management, e.g. to troubleshoot consumer and company communication. There are some literature reports about the successful use of factor analysis in managing a company area. Nevertheless, the literature seems to lack examples with successful use of the method with a clear explanation of its rather difficult application in the field of competitiveness or potential company boost. The modest popularity of such a powerful technique in this particular field seems to be attributed mainly to the complexity of the method and its requirements concerning the data quantity. Besides, the factor analysis technique has great potential and can be used as an efficient tool to reduce the complexity of observed phenomenon or verify the accuracy of theoretical models. Therefore, the purpose of this paper is to present a vast potential of factor analysis (both exploratory and confirmatory) applied to solve various problems in company management, especially related to competitiveness and market success. Two case studies covering the subject of business management are presented to illustrate the benefits of factor analysis application. The exploratory factor analysis is exemplified by the search of factors related to the commercial success of the company, while the confirmatory technique is illustrated by a case study of the intellectual capital of the company and its factors related to competitiveness. The paper also presents the essence of the factor analysis, types of analysis, subsequent procedures, purposes, and its specific features. Finally, the applicability of the factor analysis to solve management issues and possible gain in management are discussed.
\end{abstract}

KEY WORDS

factor analysis, confirmatory factor analysis, exploratory factor analysis, management

10.2478/emj-2021-0019 pages: $25-36$
Jolanta Jurczak

Faculty of Management, Warsaw University of Technology, Poland ORCID 0000-0003-2584-6427

Corresponding author: e-mail: jolanta.jurczak@pw.edu.pl

Grzegorz Jurczak

Institute of Fundamental Technological Research, Polish Academy of Sciences

Poland

ORCID 0000-0002-6978-8639

\section{INTRODUCTION}

Nowadays, contemporary businesses operate in an extremely volatile market, and competition is a crucial factor in the business environment. A shift of the client's preferences, which is difficult to predict, forces businesses to continue adjusting their market strategies to an irregular situation. In other words, successful companies have to take chances and avoid threats. Many variable management methods and techniques are reported in the Management Sciences

Jurczak, J., \& Jurczak, G. (2021). Application of factor analysis in company management — selected examples related to competitiveness and market success. Engineering Management in Production and Services, 13(3), 25-36. doi: 10.2478/emj2021-0019 
(MS) literature to support businesses in their market activity. These techniques may increase business efficiency and uprate its market value, e.g. by improving the ability to adapt the current market strategy to customer demands. One of these techniques is Factor Analysis (FA) (Vincent, 1953; Mulaik, 1987), a statistical method that looks at a complex, multivariate problem and significantly reduces its complexity using a few abstractive factors instead of numerous initial variables. Once the problem is reduced and described by abstractive common factors, the company can focus on relevant factors.

\section{LITERATURE REVIEW}

No doubt, statistical data is a powerful source of marketing information, and factor analysis (FA) as a data mining technique plays an essential role in many areas of a running business, especially related to the customers and their market behaviour (Brown, 2006; Czopek, 2014). An FA-based statistical analysis reveals the hidden structure of the market phenomenon, which may support marketing departments in decision-making based on the balance of cost, risk and opportunities. Also, adequate FA research may support intellectual capital management, leadership evaluation, innovation policy, inventory control and the rise of enterprise goodwill. Despite the possible benefits, the FA technique seems to be still underrated and underutilised in the MS field. In contrast, FA is a very widespread and noted technique within many other branches of science, e.g. social and psychological sciences and marketing research (Thurstone, 1947; Nawojczyk, 2002; Brown, 2006; Cortés Sánchez \& Grueso Hinestroza, 2017; Chidambaram et al., 2013; Ludwikowska, 2021; Warter \& Warter, 2017). The reason may be related to the lack of statistical awareness, laborious data collection, computational complexity, and problematic interpretation of abstractive factors. Also, relatively modest literature repertory offering straight guidance on applying FA to solve the problem within business management does not help to correct the situation. Nevertheless, the literature still has some reports dealing with complex management problems based on FA studies. For example, Cabuñas (2019) used the Exploratory Factor Analysis (EFA) to deal with a cost overrun in construction projects. Hawrysz (2019) studied the role of dynamic abilities on the performance of e-administration using the Confirmatory Factor Analysis (CFA). Renault (2018) analysed the risks management methods among small and medium companies. Wipulanusat (2017) used EFA to identify the leadership styles related to innovativeness in Australian Public Services. In the case of Polish companies, Jaskóła (2014) used EFA to check the main business success factors in chemical and structural companies. Jurczak (2012) used CFA to study intellectual capital factors which may create a competitive advantage in the market. Staniec (2012) used factor analysis to identify crucial problems for management systems development. Łobos (2011) dealt with income, profit, and goodwill as a universal benchmark of management success. Maciejewski (2011) studied consumer risk within the tourist industry. Zgrzywa-Ziemak (2009) dealt with the learning ability of companies.

Consequently, FA can also be used to a significant effect in management science. The FA application to deal with empirical research within MS allows determining an accurate scheme of mutual correlation between a phenomenon constituent (objects) and an accurate diagnosis about the model and its behaviour, despite the complexity of the problem. Statistical prediction resulting from FA can improve the efficiency of a company's choices in investment, finance, cost planning, risk management, intellectual capital management, leadership style, employee attitude and behaviour, client attitude, the flow up to stores or market value creation. FA is especially efficient in the case of complex problems with many possible factors that affect the behaviour of the phenomenon. As FA allows to determine the impact of each factor, the company can focus on several most important factors and thereby reduce the complexity of the problem. Such complexity is typical for management problems, especially related to learning, development, competitiveness, and success of the company in the market. Also, issues related to the measurement of intangible resources are difficult to quantify, and numerous factors may appear to generate a complicated, crosscorrelated pattern. Table 1 provides the selected literature reports on applying the factor analysis addressing management problems related to the market effectiveness, competitiveness or market success.

This paper presents examples of successful FA applications. It uses Polish companies as an example to show how to apply FA to increase competitiveness or potential. The application of the EFA technique to solve management problems is illustrated presenting the study of main factors contributing to the success in the market by Jaskóła (2014). The verification of 
Tab. 1. Diversification of the factor analysis application (EFA/CFA) to company management problems related to the market effectiveness, competitiveness or market success

\begin{tabular}{|c|c|}
\hline AUTHOR (YEAR) & EFA / CFA APPLICATION IN MANAGEMENT \\
\hline D. Leończuk (2021) & $\begin{array}{l}\text { Factors affecting the level of supply chain performance and its dimensions in the context } \\
\text { of supply chain adaptability (CFA) }\end{array}$ \\
\hline $\begin{array}{l}\text { M.A. Hedhili, } \\
\text { S. Boudabbous (2020) }\end{array}$ & $\begin{array}{l}\text { FA analysis of competence management in companies to develop and enhance employees' } \\
\text { skills }\end{array}$ \\
\hline K. Na-Nan, S. Saribut (2020) & Validation of employees' self-leadership using exploratory and confirmatory factor analysis \\
\hline L. Hawrysz (2019) & Effect of dynamic abilities on the e-administration operation (CFA) \\
\hline P. Bartkowiak (2018) & Importance of selected stakeholders in the value creation process \\
\hline $\begin{array}{l}\text { B.Y. Renault, } \\
\text { J.N. Agumbai et al. (2018) }\end{array}$ & EFA of risk management practices among small and medium contractors in Gauteng \\
\hline $\begin{array}{l}\text { V. Victor, J.J. Thoppan, } \\
\text { R.N. Jeyakumar, } \\
\text { F.M. Fekete (2018) }\end{array}$ & $\begin{array}{l}\text { Factors influencing consumer behaviour and prospective purchase decisions in a dynamic } \\
\text { pricing environment (EFA) }\end{array}$ \\
\hline $\begin{array}{l}\text { W. Wipulanusat, } \\
\text { K. Panuwatwanich, } \\
\text { R.A. Stewart (2017) }\end{array}$ & Exploring leadership styles for innovation (EFA) \\
\hline $\begin{array}{l}\text { P. Zaborek, P. Tomczyk, } \\
\text { T. Doligalski (2016) }\end{array}$ & Customer analysis as a driver of financial performance in the Polish insurance industry (EFA) \\
\hline D. Rojek (2016) & Study of strategic factors related to innovation management by EFA \\
\hline H.S. Jung, H.H. Yoon (2016) & $\begin{array}{l}\text { Effects of emotional intelligence on stress-coping styles and job satisfaction in the hospital- } \\
\text { ity industry (EFA/CFA) }\end{array}$ \\
\hline K. Jaskóła (2014) & $\begin{array}{l}\text { Searching for roots of market success among international industrial corporations within } \\
\text { the chemical and structural branch (EFA) }\end{array}$ \\
\hline J. Jurczak (2012) & $\begin{array}{l}\text { Study of factors related to the intellectual capital of the company and their role in the } \\
\text { competitive advantage (CFA) }\end{array}$ \\
\hline I. Staniec (2012) & $\begin{array}{l}\text { FA application to identify factors related to management system perfection in Polish organ- } \\
\text { isations }\end{array}$ \\
\hline $\begin{array}{l}\text { D. Gursoy, C.G.-Q. Chi, } \\
\text { E. Karada (2012) }\end{array}$ & $\begin{array}{l}\text { Generational differences in work values and attitudes among frontline and service contact } \\
\text { employees verified through EFA }\end{array}$ \\
\hline $\begin{array}{l}\text { K. Łobos, } \\
\text { M. Szewczyk (2011) }\end{array}$ & $\begin{array}{l}\text { FA study of income, profit and company value as a universal success measure (effective- } \\
\text { ness) of the company management }\end{array}$ \\
\hline $\begin{array}{l}\text { A. Zgrzywa-Ziemak, } \\
\text { R. Kamiński (2009) }\end{array}$ & Study of the factors related to the organisation learning (CFA) \\
\hline $\begin{array}{l}\text { Ch. Burmann, S. Zeplin, } \\
\text { N. Riley (2009) }\end{array}$ & Key determinants of internal brand management success (EFA) \\
\hline D. Turker (2009) & Measuring corporate social responsibility (EFA) \\
\hline $\begin{array}{l}\text { R. Škrinjar, V. Bosilj-Vukšić, } \\
\text { M. Indihar-Štemberger (2008) }\end{array}$ & FA in the impact of business process orientation on financial and non-financial performance \\
\hline C. Brooke-Dobni (2008) & Measuring innovation culture in organisations (EFA) \\
\hline $\begin{array}{l}\text { J. Garczarczyk, } \\
\text { M. Mocek (2006) }\end{array}$ & FA study of the quality of insurance services \\
\hline $\begin{array}{l}\text { C.L. Wang, } \\
\text { P.K. Ahmed (2004) }\end{array}$ & Development and validation of the organisational innovativeness construct using CFA \\
\hline
\end{tabular}

Source: elaborated by the author based on Internet search (keywords: exploratory factor analysis in company management; confirmatory factor analysis in company management, Google Scholar). 
the intellectual capital (IC) model and its ability to create a competitive advantage in the market done by Jurczak (2012) is described as an application of the CFA technique. The above examples cover complex matters that are difficult to measure directly, making them ideal for the factor analysis methodology.

\section{Methodology}

FA was initially developed and applied to deal with problems of complex human abilities. The method was proposed by Thurstone (1933) on the grounds of earlier works by Spearman (1904) and Pearson (1901). The goal of the method is to identify rather abstractive and hidden factors which constitute the problem as distinct from really measured variables. FA analyses survey data to find out hidden constructs, their mutual interrelation and complicity with measured variables. Replacing numerous initial variables with a limited set of factors makes the analysis relatively simple. Factors, contrary to initial variables, also possess a more general and universal character and may facilitate theoretical interpretation of the problem. According to specific goals of analysis, factor analysis is divided into exploratory and confirmatory branches. The goal of the exploratory analysis is to reveal the hidden structure of the phenomenon described by a set of measurable variables. It starts from scratch without the need to know the problem during the preliminary calculation; however, this knowledge is essential for interpreting results. Confirmatory analysis tests whether a set of factors specified by the theoretical model satisfyingly reproduces observed responses; thus, the technique needs the model to test its matching to the observations. The main assumption is to use a linear combination of (yet unknown) factors (including the specific factor) to reproduce the variation of initial variables. The problem is to determine these unknown factors accurately. The factor analysis methodology consists of several statistical procedures that can be group as follow:

- the input data check (the amount, completeness, and quality of the data),

- the applicability of the method check (the fitness of the data, Cronbach's alpha, Kaiser-MeyerOlkin criterion),

- the factor estimation (the revelation of the hidden structure of the problem),

- the factor selection (the reduction of the problem's dimension),
- the factor rotation (highlighting selected factors and the depletion of others: Varimax, Biquartimax, Equamax),

- the interpretation of results.

Above, the abridged description of the method is provided while more comprehensive information is offered, e.g. by Frątczak (2009).

\section{RESULTS OF SEARCHING FOR MARKET SUCCESS SOURCES}

Scientific research by Jaskóła aimed to identify the root of commercial success within the mediumand large-sized petroleum and construction companies, as well as their cooperative businesses located in Poland. Results were presented in his work "Geneza sukcesu. Dynamiczne zarządzanie korporacjami przemysłowymi" (Genesis of the success. Dynamic management of industry corporations; Jaskóła, 2014; in Polish). The author studied many parameters affecting company activity in the market and its development to find their relationship to commercial success. Based on the survey of executive managers, EFA showed the underlying structure of the issue and pointed out the main success factors having the highest contribution. The survey research comprised 38 variables related to the activity of various companies or their assets. Variables were initially assumed to comprise the company success in the market. The total number of respondents was 116 from 24 companies. The FA goal was to reduce the complexity of statistical data in questionnaires by lumping highly interrelated variables and revealing a more general structure of the problem. The analysis of common factors with respect to factor loadings revealed factors constituting the basis for success and information about their structure.

As is usual in the case of FA, the first step of the analysis was to check the data for correctness and usefulness for the factor analysis. The correlation matrix was calculated after the data adequacy verification for reducing the dimensionality (by KaiserMeyer-Olkin and Bartlet's tests). Eigenvectors of the correlation matrix were sorted according to their eigenvalues, which allows selecting an adequate number of common factors for further analysis. The application of various criteria for eigenvector selection usually results in a number of factors between 4 and 12. Initial, unrotated eigenvalues have rather low values, and in this case, only one was significantly greater than 1.0, whereas consecutive eigenvalues 
Tab. 2. Factors determining the success of the company and their components

\begin{tabular}{|c|c|c|}
\hline No & COMMON FACTOR & INITIAL VARIABLES \\
\hline I & market activity & $\begin{array}{l}\text { 1. product, } \\
\text { 2. market, } \\
\text { 4. active marketing, } \\
\text { 11. business and economic surroundings, } \\
\text { 17. active, sometimes an aggressive activity in the market, } \\
\text { 24. product innovations, } \\
\text { 27. marketing innovations }\end{array}$ \\
\hline II & leader efficiency & $\begin{array}{l}\text { 10. management style, } \\
\text { 19. resourcefulness of the leader, } \\
\text { 20. creativity of the leader, } \\
\text { 21. innovativeness of the leader, } \\
\text { 23. openness to changes, } \\
\text { 22. problems of the staff }\end{array}$ \\
\hline III & technological innovativeness & $\begin{array}{l}\text { 5. advanced technologies, } \\
\text { 13. technological surroundings, } \\
\text { 18. technological development and product refining, } \\
\text { 25. technological innovations, } \\
\text { 35. IT technologies }\end{array}$ \\
\hline IV & employee competence & $\begin{array}{l}\text { 3. peoples and systems, } \\
\text { 6. system of values, } \\
\text { 8. knowledge and staff competences, } \\
\text { 9. job motivation }\end{array}$ \\
\hline
\end{tabular}

Source: (Jaskóła, 2014).

were just around 1.0. To bring out other eigenvalues, the Varimax rotation was used and three subsequent eigenvalues were significantly raised. Finally, four common factors were assumed as an appropriate factor set for further analysis. So, the underlying structure of the survey has four common factors loaded by initial variables (Table 2).

Theoretical senses of common factors were determined and attributed to market activity, leader and staff competences, and technological innovativeness. To verify mutual variable-factor interrelations, factor loadings were examined (Table 3). Typically, the cut-off point for loading meaningfulness is 0.7 (0.6 in some cases). The analysis of factor loadings allowed matching 22 of the initial 38 variables to explain the structure of the phenomenon. The cumulative variation reproduced by the underlying structure consisting of four common factors is about $50 \%$ - 59\% of the initial variance (the result depends on the assumed methodology). The factor-related percentage explanation of the initial variation was equal, respectively, I:16-18\%, II:12-15\%, III:11-14\%, IV:10$12 \%$.

Further studies proved the existence of a strong relationship between the first factor (market activity) and subsequent factors, especially in the case of leader efficiency (factor II) and employee competence (factor III), see Table 4 . It can be easily explained as a mutual relationship between market activity, quality of the leadership and competences of the staff. An opposite relationship also exists as a skilled leader by different actions or professional staff development may improve the employer competitiveness, and therefore, lead to the success in the market. Also, employee competence expressed by skilled staff able to handle innovative products may stimulate the company's development by reaching customer expectations. Also, the market activity depends on technological innovativeness and vice versa. Such a relationship can be explained by the role of technological advances and their practical implementation, allowing to reach a competitive advantage in the market. Technological innovativeness also affects leadership efficiency by providing efficient tools for production management on the one hand, and on the other hand, requiring continuous professional development of the executive management to handle these new technologies.

The commercial success of examined companies has been generally attributed to the management activity and their multifold actions, continuously increasing the company's competitiveness and streamlining market activity. The commercial success was also stimulated by a significant contribution of competent staff and continuous investments in and implementation of new technologies. 
Tab. 3. Selected variables, their factor loadings, and the cumulative variation (the principal component method after the Biquartimax rotation)

\begin{tabular}{|c|c|c|c|c|c|}
\hline No & INITIAL VARIABLE & FACTOR I & FACTOR II & FACTOR III & FACTOR IV \\
\hline $\begin{array}{l}1 . \\
2 . \\
3 . \\
4 . \\
5 . \\
6 . \\
8 . \\
9 . \\
10 . \\
11 . \\
13 . \\
17 . \\
18 . \\
19 . \\
20 . \\
21 . \\
22 . \\
23 . \\
24 . \\
25 . \\
27 . \\
35 .\end{array}$ & $\begin{array}{l}\text { product, } \\
\text { market, } \\
\text { peoples and systems, } \\
\text { active marketing, } \\
\text { advanced technologies, } \\
\text { system of values, } \\
\text { knowledge and staff competences, } \\
\text { job motivation, } \\
\text { management style, } \\
\text { business and economic surroundings, } \\
\text { technological surroundings, } \\
\text { active, sometimes an aggressive activity in the market, } \\
\text { technological development and product refining, } \\
\text { resourcefulness of the leader, } \\
\text { creativity of the leader, } \\
\text { innovativeness of the leader, } \\
\text { problems of the staff, } \\
\text { openness to changes, } \\
\text { product innovations, } \\
\text { technological innovations, } \\
\text { marketing innovations, } \\
\text { IT technologies }\end{array}$ & $\begin{array}{l}0.731 \\
0.764 \\
0.731 \\
0.728\end{array}$ & $\begin{array}{l}0.716 \\
0.746 \\
0.742 \\
0.753 \\
0.689\end{array}$ & $\begin{array}{l}0.730 \\
0.811\end{array}$ & $\begin{array}{l}0.834 \\
0.792 \\
0.705\end{array}$ \\
\hline & Cumulative variation: $58.92 \%$ & $18.32 \%$ & $14.76 \%$ & $13.63 \%$ & $12.21 \%$ \\
\hline
\end{tabular}

Source: (Jaskóła, 2014).

Tab. 4. Relationships between common factors

\begin{tabular}{|c|c|c|}
\hline FACTOR & FACTOR & $\begin{array}{c}\text { INTERRELATION } \\
\text { MEASURE }\end{array}$ \\
\hline market activity & leader efficiency & 0.180 \\
\hline market activity & $\begin{array}{c}\text { technological } \\
\text { innovativeness }\end{array}$ & 0.120 \\
\hline market activity & employee competence & 0.170 \\
\hline leader efficiency & $\begin{array}{c}\text { technological } \\
\text { innovativeness }\end{array}$ & 0.155 \\
\hline leader efficiency & employee competence & 0.092 \\
\hline $\begin{array}{c}\text { technological } \\
\text { innovativeness }\end{array}$ & employee competence & 0.054 \\
\hline
\end{tabular}

Source: (Jaskóła, 2014).

\section{RESULTS OF THE INTELLECTUAL CAPITAL'S ABILITY TO GAINING COMPETITIVE ADVANTAGE}

The ability of the company's IC to affect its competitiveness in the market may be studied by factor analysis as well to reveal underlying constructs governing the problem and interpret their general meaning. As stated above, in the case of analysis from scratch, exploratory techniques should be used. However, to verify the already assumed model which describes observed cases, CFA should be used instead. The presented example concerns the confirmatory technique used to verify the already assumed model of the company's IC and its impact on competitive advantage in the market. Empirical studies were conducted by Jurczak (2012) on the grounds of survey research of 186 Polish consulting firms. The survey allowed to create an initial theoretical IC model and propose the model describing its market mechanism affecting the competitiveness. At first, a preliminary EFA analysis was conducted to give a theoretical background for an adequate model of the IC ability to gain competitive advantage.

According to the rules, the reliability of test scores and the internal scale consistency were verified at the beginning of the EFA analysis. Next, Cronbach's alpha, KMO, and Bartlet's measures were calculated. The revealed hidden structure of the phenomenon allows constructing a theoretical model based on four IC components boosting competitive advantage, namely, knowledge and skills of employees, mutual trust and cooperation, communication processes within the company, and public image and reputation of the company. Figure 1. shows a simplified path model of the IC ability to gain competitive advantage with subsequent factor loadings on the basis of an exploratory analysis. A full theoretical path model of the IC ability to gain competitive advantage is pre- 


\begin{tabular}{|c|c|c|}
\hline Knowledge and skills of employee & \multirow{3}{*}{\multicolumn{2}{|c|}{ 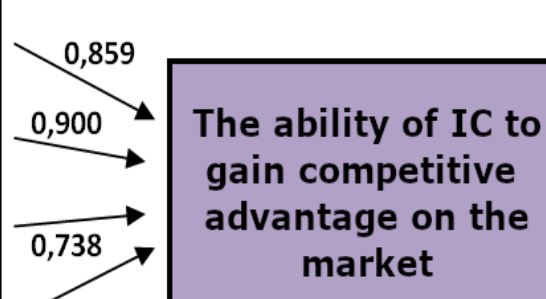 }} \\
\hline Mutual trust and cooperation & & \\
\hline Communication processes within company & & \\
\hline Public image and reputation on the mark & & \\
\hline
\end{tabular}

Fig. 1. Simplified path model of the IC ability to gain competitive advantage with factor loadings Source: (Jurczak, 2012).

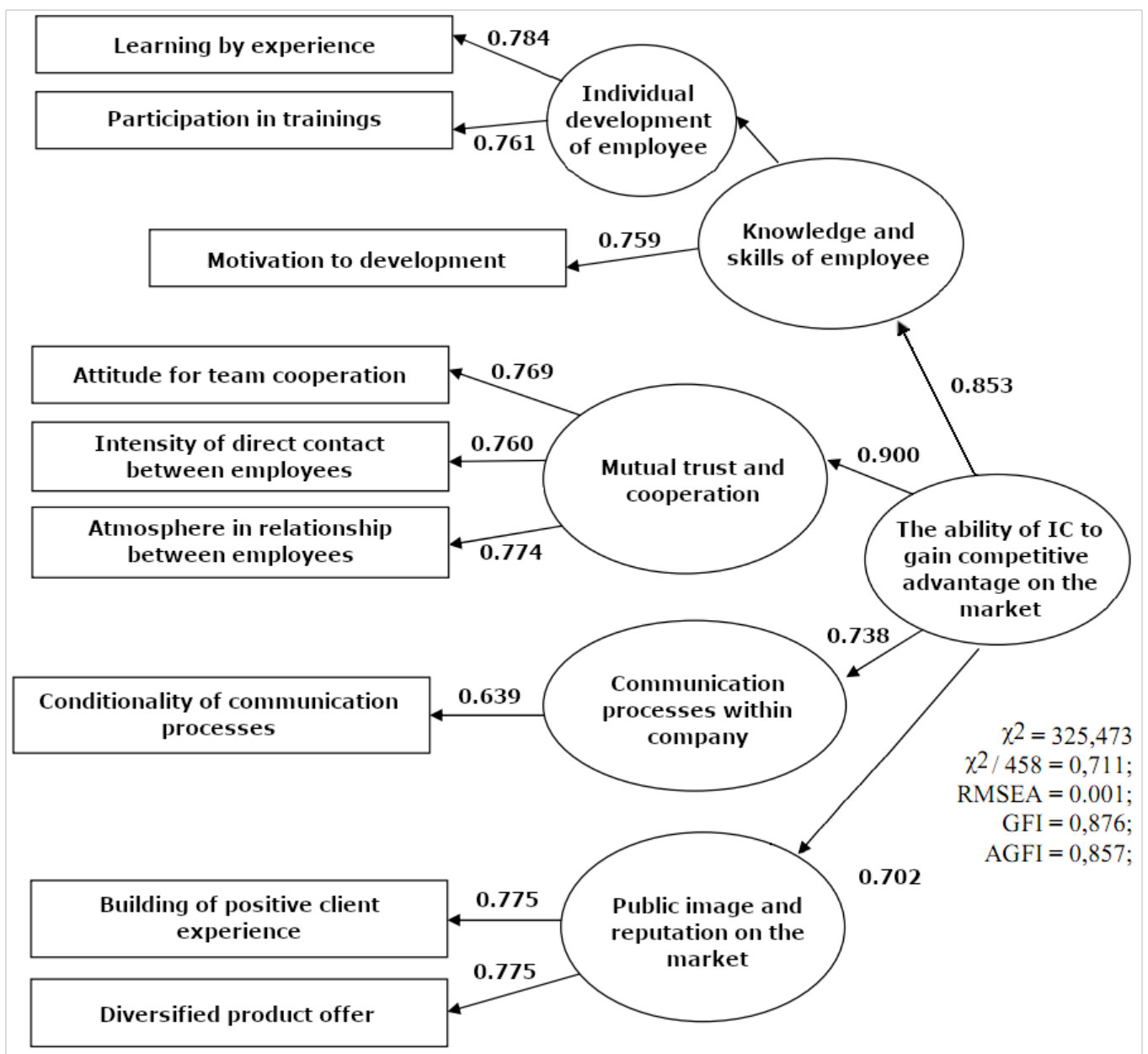

Fig. 2. Theoretical path model of the IC ability to gain competitive advantage with calculated fitting indices and factor loadings Source: (Jurczak, 2012).

sented in Figure 2. Each factor was described by a basic hypothesis and more detailed specific hypotheses. Table 5 provides the structure of the problem based on common factors, related initial variables with options, and research hypotheses.
Next, CFA was carried out to verify the accuracy of the assumed model. To test the accuracy of the proposed model, CFA uses structural equation modelling and checks if factor loadings confirm the assumed relationships between measured variables 
and underlying factors. The hypothesised model is tested against observed variables, and the analysis also demonstrates the relationship between respective factors. To quantitatively evaluate the accuracy of the model and its ability to reproduce the initial data variance, the following fit indices were used:

- chi square statistic $-\chi^{2}$ /degree of freedom (dof),

- Steiger-Lind's root mean square error of approximation - RMSEA,

- Joreskog's goodness of fit index - GFI,
- $\quad$ adjusted goodness of fit index - AGFI.

General fitting parameters of the hypothesised model are presented in Figure 2, next to the path model, while partial fitting measures in the case of separated factors within the model are presented in Table 6. The statistical analysis of particular factors that are assumed in the proposed model shows that the fitting quality is relatively high, despite the used fitting index. The basic $\chi^{2}$ /dof index shows that the proposed model has an excellent fit with polling data.

Tab. 5. Assumed hypotheses and common factor structure connected with initial variables related to the IC ability to gain competitive advantage

\begin{tabular}{|c|c|c|c|c|}
\hline FACTOR & BASIC HYPOTHESIS & SPECIFIC HYPOTHESIS & VARIABLES & OPTIONS \\
\hline \multirow{10}{*}{ 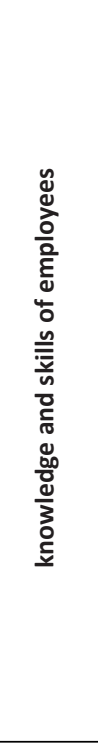 } & \multirow{10}{*}{$\begin{array}{l}\text { H1: The more profound } \\
\text { is knowledge and higher } \\
\text { skills of employees, the } \\
\text { higher ability of the } \\
\text { company's IC to gain a } \\
\text { competitive advantage in } \\
\text { the market }\end{array}$} & \multirow{3}{*}{$\begin{array}{l}\text { H1_1: The faster employ- } \\
\text { ees gain the knowledge } \\
\text { and improve skills, the } \\
\text { higher is the knowledge } \\
\text { and skills of employees }\end{array}$} & \multirow[t]{3}{*}{$\begin{array}{l}\text { Learning by } \\
\text { experience }\end{array}$} & $\begin{array}{l}\text { Less experienced employees are mobilised } \\
\text { to observe more experienced employees }\end{array}$ \\
\hline & & & & $\begin{array}{l}\text { More experienced employees are trainers } \\
\text { and advisers for less experienced employ- } \\
\text { ees }\end{array}$ \\
\hline & & & & $\begin{array}{l}\text { Changing the occupation in the enterprise } \\
\text { deepens the knowledge and expedites the } \\
\text { development of skills of employees }\end{array}$ \\
\hline & & \multirow{7}{*}{$\begin{array}{l}\text { H1_2: The more intense is } \\
\text { the motivation of employ- } \\
\text { ees for professional devel- } \\
\text { opment and improvement } \\
\text { of skills, the higher is the } \\
\text { knowledge and skills of } \\
\text { employees }\end{array}$} & \multirow{4}{*}{$\begin{array}{l}\text { Participation in } \\
\text { training }\end{array}$} & Training in the occupation \\
\hline & & & & Discussion within the team \\
\hline & & & & Case-study \\
\hline & & & & Lectures \\
\hline & & & \multirow{3}{*}{$\begin{array}{l}\text { Motivation to } \\
\text { develop }\end{array}$} & Fixing different and complicated tasks \\
\hline & & & & $\begin{array}{l}\text { Granting a bonus for improving processes } \\
\text { and products of the company }\end{array}$ \\
\hline & & & & $\begin{array}{l}\text { Participation in formulating the purpose of } \\
\text { the enterprise }\end{array}$ \\
\hline \multirow{9}{*}{ 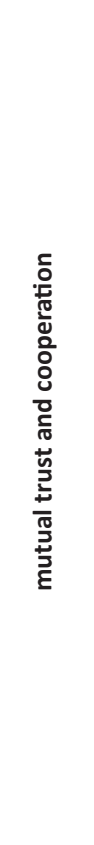 } & \multirow{9}{*}{$\begin{array}{l}\text { H2: The higher is the } \\
\text { value of the relationship } \\
\text { based on mutual trust and } \\
\text { cooperation, the higher } \\
\text { is the IC ability to gain a } \\
\text { competitive advantage in } \\
\text { the market }\end{array}$} & \multirow{4}{*}{$\begin{array}{l}\text { H2_1: The more appre- } \\
\text { ciation is given to team } \\
\text { building in the company, } \\
\text { the higher is mutual trust } \\
\text { and cooperation }\end{array}$} & \multirow[t]{2}{*}{$\begin{array}{l}\text { Attitude for } \\
\text { team coopera- } \\
\text { tion }\end{array}$} & $\begin{array}{l}\text { Cooperation within the team helps em- } \\
\text { ployees realise complicated daily tasks }\end{array}$ \\
\hline & & & & $\begin{array}{l}\text { Cooperation can lead to a breakthrough } \\
\text { in thinking }\end{array}$ \\
\hline & & & \multirow[t]{3}{*}{$\begin{array}{l}\text { Intensity of } \\
\text { direct contact } \\
\text { between em- } \\
\text { ployees }\end{array}$} & $\begin{array}{l}\text { Employees contact each other about } \\
\text { problems concerning the development of } \\
\text { products and services within the enter- } \\
\text { prise permanently and systematically }\end{array}$ \\
\hline & & & & $\begin{array}{l}\text { Special emphasis is put on the develop- } \\
\text { ment of interpersonal contacts within the } \\
\text { enterprise }\end{array}$ \\
\hline & & \multirow{3}{*}{$\begin{array}{l}\text { H2_2: The more frequent } \\
\text { are direct contacts be- } \\
\text { tween employees, the } \\
\text { higher is the mutual trust } \\
\text { and cooperation }\end{array}$} & & $\begin{array}{l}\text { Informal rules and norms of operations } \\
\text { dominate in the enterprise }\end{array}$ \\
\hline & & & \multirow[t]{4}{*}{$\begin{array}{l}\text { Atmosphere in } \\
\text { employee rela- } \\
\text { tionships }\end{array}$} & Lack of involvement vs. involvement \\
\hline & & & & Lack of trust vs. trust \\
\hline & & \multirow{2}{*}{$\begin{array}{l}\text { H2_3: The better is the } \\
\text { work atmosphere in the } \\
\text { company, the higher is } \\
\text { mutual trust and coopera- } \\
\text { tion }\end{array}$} & & $\begin{array}{l}\text { Stagnation vs. orientation on the develop- } \\
\text { ment }\end{array}$ \\
\hline & & & & Secrecy vs. openness \\
\hline
\end{tabular}




\begin{tabular}{|c|c|c|c|c|}
\hline FACTOR & BASIC HYPOTHESIS & SPECIFIC HYPOTHESIS & VARIABLES & OPTIONS \\
\hline \multirow{7}{*}{ 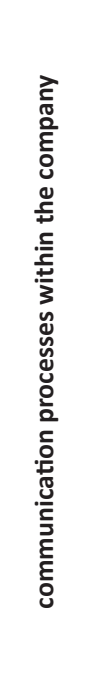 } & \multirow{7}{*}{$\begin{array}{l}\text { H3: The more efficient are } \\
\text { communication processes } \\
\text { in the company, the high- } \\
\text { er is the IC ability to gain a } \\
\text { competitive advantage in } \\
\text { the market }\end{array}$} & \multirow{4}{*}{$\begin{array}{l}\text { H3_1: The more system of } \\
\text { information fosters spon- } \\
\text { taneous communication, } \\
\text { the higher is the quality of } \\
\text { communication processes } \\
\text { between employees } \\
\text { within the company }\end{array}$} & \multirow{7}{*}{$\begin{array}{l}\text { Conditionality } \\
\text { of communica- } \\
\text { tion processes }\end{array}$} & $\begin{array}{l}\text { Informal flow of information and knowl- } \\
\text { edge exists in the organisation }\end{array}$ \\
\hline & & & & $\begin{array}{l}\text { Employees are encouraged to develop the } \\
\text { dialogue and discussion within the com- } \\
\text { pany }\end{array}$ \\
\hline & & & & $\begin{array}{l}\text { Flow of information and knowledge be- } \\
\text { tween employees is intense and easy }\end{array}$ \\
\hline & & & & $\begin{array}{l}\text { Image of the firm in the employees' eyes is } \\
\text { formed by intense communication via dedi- } \\
\text { cated channels }\end{array}$ \\
\hline & & \multirow{3}{*}{$\begin{array}{l}\text { H3_2: The more differ- } \\
\text { entiated are the means } \\
\text { of communication, the } \\
\text { higher is the quality of } \\
\text { communication processes } \\
\text { between employees } \\
\text { within the company }\end{array}$} & & $\begin{array}{l}\text { Channels of communication connected } \\
\text { with information passing are used intensely }\end{array}$ \\
\hline & & & & $\begin{array}{l}\text { Channels of direct communications and re- } \\
\text { lationships are used intensely }\end{array}$ \\
\hline & & & & $\begin{array}{l}\text { Different ways of communication which } \\
\text { boost knowledge and enable reaching } \\
\text { numbers of people are used widely within } \\
\text { the enterprise }\end{array}$ \\
\hline \multirow{6}{*}{ 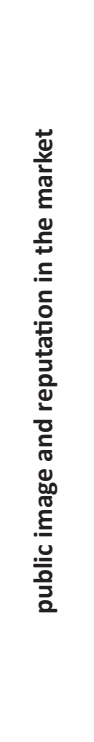 } & \multirow{6}{*}{$\begin{array}{l}\text { H4: The higher is the } \\
\text { care for the public im- } \\
\text { age and reputation of } \\
\text { the company, the higher } \\
\text { is the IC ability to gain a } \\
\text { competitive advantage in } \\
\text { the market }\end{array}$} & \multirow{4}{*}{$\begin{array}{l}\text { H4_1: The more the mar- } \\
\text { keting communication } \\
\text { system fosters the build- } \\
\text { ing of positive experiences } \\
\text { between clients and the } \\
\text { organisation, the higher } \\
\text { is the care for the public } \\
\text { image and reputation of } \\
\text { the company }\end{array}$} & \multirow[t]{3}{*}{$\begin{array}{l}\text { Building a posi- } \\
\text { tive client expe- } \\
\text { rience }\end{array}$} & $\begin{array}{l}\text { Aspiration of the enterprise for getting the } \\
\text { highest quality of offered products and } \\
\text { services is visible }\end{array}$ \\
\hline & & & & $\begin{array}{l}\text { Systematic growth of the cooperation with } \\
\text { clients (or potential clients) is practised to } \\
\text { satisfy their wants and requirements }\end{array}$ \\
\hline & & & & $\begin{array}{l}\text { Aspiration of the enterprise for getting the } \\
\text { highest quality of client service is visible }\end{array}$ \\
\hline & & & \multirow[t]{3}{*}{$\begin{array}{l}\text { Diversified } \\
\text { product offer }\end{array}$} & $\begin{array}{l}\text { Efforts of the enterprise aimed at a devel- } \\
\text { oping product and service offer most often } \\
\text { concentrate on building innovative prod- } \\
\text { ucts and services }\end{array}$ \\
\hline & & \multirow{2}{*}{$\begin{array}{l}\text { H4_2: The more diversi- } \\
\text { fied is the product offer, } \\
\text { the higher is the care } \\
\text { for the public image and } \\
\text { reputations of the com- } \\
\text { pany }\end{array}$} & & $\begin{array}{l}\text { Enterprise is perfect in the creation of new } \\
\text { kinds of products and services }\end{array}$ \\
\hline & & & & $\begin{array}{l}\text { Strategy realised by the enterprise relies on } \\
\text { the implementation of numerous and dy- } \\
\text { namic changes in the product-service offer } \\
\text { to give clients the best product }\end{array}$ \\
\hline
\end{tabular}

Source: (Jurczak, 2012).

Partial indices $\chi 2 /$ dof corresponding to each factor of the model are less than $2(\chi 2 /$ dof $<2)$, which is commonly assumed as a good fitting of the model. Partial indexes of the RMSEA are in the range 0.00-0.05, while the critical value for the quality of the model is 0.1 . Moreover, even such sophisticated and challenging indices as GFI and AGFI in the case of subsequent factors exceed the 0.9 value, which confirms the good quality of the model components. Basic statistics of the fitting quality in the case of a complete model are equal to 0.711 for the $\chi 2 /$ dof index and 0.001 for the RMSEA index. More advanced GFI and AGFI indices do not exceed the recommended value of 0.9 in this case. They are equal to 0.876 and 0.857 , respectively. Lower than expected values of GFI and AGFI fitting indexes do not immediately attest to the poor quality of the model. Calculated values of fitting indexes, in the case of a complex model, usually are low, and in this case, the result can be treated as a rather satisfying fitting. Such a situation is typical in the case of complex model analysis, and it suggests the need for further improvements within the proposed model. Because of the relatively high fitting of compositional factors, the model improvement should be realised mainly by considering an alternate factor that may improve the fitting index of the model as a whole.

A closer look at the model and factor loadings points out the importance of the mutual trust and cooperation factor. Factor loading equal to 0.9 indicates the best matching with measured data and sug- 
Tab. 6. Partial fitting statistics for each component of the IC model in getting a competitive advantage

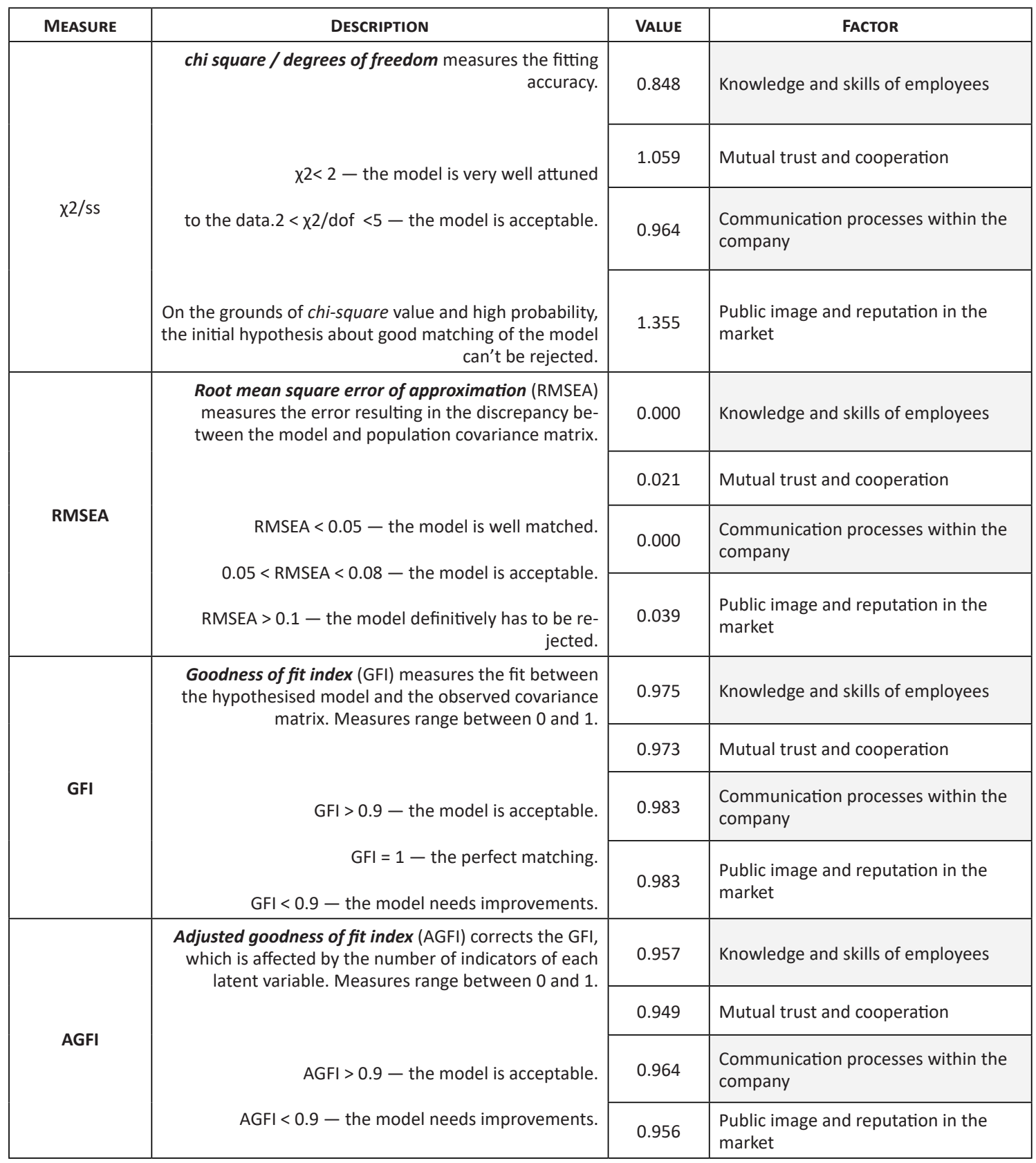

Source: (Jurczak, 2012).

gests its importance within the model of the IC ability to gain competitive advantage. Another common factor with a high value of factor loading is the level of employee knowledge and skills. This factor also constitutes an important contribution to the IC ability. The remaining factors with lower values of factor loadings (which are still significant, i.e. 0.73 and 0.70 ) constitute supplementary factors of the IC ability to gain competitive advantage.

\section{DISCUSSION}

Generally, factor analysis as a research tool in business management is rare as its application involves some difficulties. On the one hand, the key points are rather limited awareness of the FA potential and complicated and challenging methodology (the sample size and result interpretation) on the other, extensive experience is required to perform 
factor analysis and avoid misinterpretation of revealed factors. Presented FA studies, both exploratory in the case of market success and confirmatory in the case of intellectual capital, illustrate successful applications within business management. The presented studies show how to reduce a large number of initial variables and replace them with several common factors without losing the quality of the description. The complementary use of factor analysis techniques, namely, the exploratory FA first and the confirmatory FA next, allow for model creation and its verification by comparison with experimental data. As presented above, FA allows revealing several factors and attributing its general meaning to such an intangible phenomenon as market value or competitive advantage of the company. It is possible to evaluate the influence of the underlying factors in the creation process of added value, competitive advantage, or just to evaluate benefits related to company assets of any kind. Factor analysis results indicate that exploratory and confirmatory analyses allow studying complex problems within the management of company competitiveness with high accuracy and reliability. Its use may lead to the formulation of more accurate theoretical models, well-tailored to given measurements, and give more accurate tools to predict the future. The use of FA positively affects the quality of theoretical models within business management. From this point of view, FA is applied to define company standards within complex problems of business management. Nevertheless, FA procedures are rather complicated, so extensive experience and caution are required along with sophisticated software to perform the time-consuming calculation.

\section{CONCLUSION}

Despite the enormous potential, there are still many issues related to the FA application and barriers to its popularisation as a common research technique within management sciences. The first barrier is the complicated nature of FA, but maybe a more important issue is the lack of awareness about the factor analysis and its potential within management practice. The literature dealing with the problem lacks reports which may introduce the inexperienced reader to the use of FA in company management. Its application needs a good understanding of FA principles, assumptions, threats and theoretical knowledge supported by experience to give a correct meaning to the revealed structure of the problem. Therefore FA, much like other statistical methods, is also based on researcher competences and makes the procedure slightly arbitrary. E.g. the choice of factors is completely subjective and based on personal experience. The same concerns interpretation of the factor meaning. It requires knowledge and can hardly be formulated in any rigorous form. Fortunately, the application of different criteria to verify and compare results allows drawing general conclusions of the analysis. Summing up, experience and knowledge in the field of studied cases remain the most important factor for the successful application of FA in management sciences.

\section{LITERATURE}

Brown, T. A. (2006). Confirmatory Factor Analysis for Applied Research. New York - London: The Guilford Press.

Cabuñas, J. T., \& Silva, D. L. (2019). Exploratory FactorItem Analytic Approach for Construction Project Cost Overrun using Oblique Promax Rotation for Predictors Determination. International Journal of Innovative Technology and Exploring Engineering, $8(6 \mathrm{~s} 3), 47-54$.

Chidambaram, V., Ramachandran, A., \& Thevar, S. S. (2013). A study on efficacy of induction training programme in Indian railways using factor analysis. Business: Theory and Practice, 14(2), 140-146. doi: 10.3846/btp.2013.15

Cortés Sánchez, J. D., \& Grueso Hinestroza, M. P. (2017). Factor analysis evaluation of Schein's career orientations inventory in Colombia. Business: Theory and Practice, 18, 186-196. doi: 10.3846/btp.2017.020

Czopek, A. (2013). Analiza porównawcza efektywności metod redukcji zmiennych - analiza składowych głównych i analiza czynnikowa [Comparative Analysis of Effectiveness of the Methods for Reduction of Variables - Principal Component Analysis and Factor Analysis]. Studia Ekonomiczne, 13, 7-23.

Frątczak, E. (2009). Wielowymiarowa analiza statystyczna. Teoria, przykłady, zastosowań z systemem SAS [Multivariate Statistical Analysis. Theory and Application with SAS]. Warszawa, Poland: Wydawnictwo SGH.

Górniak, J., \& Wachnicki, J. (2010). Pierwsze kroki w analizie danych [The first steps towards data analysis]. Kraków, Poland: SPSS Polska.

Hawrysz, L. (2019). Wpływ zdolności dynamicznych na funkcjonowanie e-administracji [Effect of dynamic abilities on the e-administration operation]. Radom, Poland: Instytut Technologii Eksploatacji - PIB w Radomiu.

Jaskóła, K. (2014). Geneza sukcesu. Dynamiczne zarządzanie korporacjami przemystowymi [Genesis of the success. Dynamic management of industry corporations]. Radom, Poland: Instytut Technologii Eksploatacji PIB w Radomiu.

Jurczak, J. (2012). Czynniki ksztaltujące kapitał intelektu- 
alny $w$ osiaganiu przewagi konkurencyjnej [Factors related to the intellectual capital of the company and their role in the competitive advantage]. $\mathrm{PhD}$ thesis. Wrocław, Poland: Politechnika Wrocławska.

Jurczak, J. (2015). Badanie kapitału intelektualnego metodą analizy czynnikowej [Factor analysis study of the intellectual capital]. Przedsiębiorstwo Przyszłości, 3(24), 48-58.

Łobos, K., \& Szewczyk, M. (2011). Wartość jako uniwersalna miara sukcesu w zarządzaniu przedsiębiorstwem [Value as universal measure of success in enterprise's management]. Management Sciences, 8, 379-388.

Ludwikowska, K. (2021). The mediating role of employeeoriented human resource policy in the relationship between strategic human resource management and organisational performance. Forum Scientiae Oeconomia, 9(2), 131-150. doi: 10.23762/FSO_VOL9_ $\mathrm{NO} 2 \_7$

Maciejewski, G. (2011). Wykorzystanie analizy czynnikowej w badaniach konsumenckiego ryzyka [The use of factor analysis in consumer risk research]. Prace naukowe Uniwersytetu Ekonomicznego we Wrocławiu, 236, 192-202.

Mulaik, S. A. (1987). A Brief History of the Philosophical Foundations of Exploratory Factor Analysis. Multivariate Behavioral Research, 22(3), 267-305.

Nawojczyk, M. (2002). Przewodnik po statystyce dla socjologów [Statistics guide for sociologists]. Kraków, Poland: SPSS Polska.

Pearson, K. (1901). On Lines and Planes of Closest Fit to Systems of Points in Space. Philosophical Magazine, 2, 559 .

Renault, B. Y., Agumba, J. N., \& Ansary, N. (2018). An exploratory factor analysis of risk management practices: A study among small and medium contractors in Gauteng. Acta Structilia, 25(1), 1-39.

Sagan, A. (2003). Model pomiarowy satysfakcji i lojalności [Metrological model of satisfaction and loyalty]. StatSoft Polska.

Spearman, C. (1904). General intelligence, objectively determined and measured. American Journal of Psychology, 15, 201-293.

Staniec, I. (2012). Analiza czynnikowa w identyfikacji obszarów determinujących doskonalenie systemów zarządzania w polskich organizacjach [Factor analysis in the identification of areas that determine the improvement of management systems in Polish organizations]. Prace Naukowe Uniwersytetu Ekonomicznego we Wrocławiu, 242, 406-415.

Sztemberg-Lewandowska, M. (2008). Analiza czynnikowa $w$ badaniach marketingowych [Factor analysis in marketing research]. Wrocław, Poland: Wydawnictwo Uniwersytetu Ekonomicznego we Wrocławiu.

Thurstone, L. L. (1933). A Simplified Multiple-factor Method. Chicago: University of Chicago Press.

Thurstone, L. L. (1947). Multiple factor analysis. Chicago: University of Chicago Press.

Vincent, D. F. (1953). The Origin and Development of Factor Analysis. Journal of the Royal Statistical Society. Series C (Applied Statistics), 2(2), 107-117.
Warter, L., \& Warter, I. (2017). Unmasking post-merger challenges: synergy effects achieved by the integration of different areas. Forum Scientiae Oeconomia, 5(2), 69-85. doi: 10.23762/fso_vol5no2_17_6

Wipulanusat, W., Panuwatwanich, K., \& Stewart, R. A. (2017). Exploring leadership styles for innovation: an exploratory factor analysis. Engineering Management in Production and Services, 9(1), 7-17.

Zgrzywa-Ziemak, A., \& Kamiński, R. (2009). Rozwój zdolności uczenia się przedsiębiorstwa [Development of business learning ability]. Warszawa, Poland: Difin. 